\title{
Methimazole-disulfide as an Anti-thyroid Drug Metabolite Catalyzed the Highly Regioselective Conversion of Epoxides to Halohydrins with Elemental Halogens
}

\author{
H. Eshghi," S. F. Tayyari, Z. Rezvani-Amin, and H. Roohi ${ }^{\dagger}$ \\ Department of Chemistry Ferdowsi Lniversity of Hashhad, Mashhad 91775-1436, Iran. *E-mail: heshghiaferdowsi.um.ac ir \\ ${ }^{\dagger}$ Deparment of Chemistry, Sistan \& Baluchestan Universitv, Zahedan 98135-674, Iran \\ Recerved Hav 31, 2007
}

\begin{abstract}
The regioselective ring opening of epoxides using elemental iodine and bromine in the presence of methimazole (MMI a anti-thy roid dnig) and its metabolite methimazole-disulfide as new catalysts are studied. MMI easily converted in vitro to MMI-disulfide without any double activation presented in wivo. FT-Raman and UV spectroscopies are used to study the interaction of iodine with these catalysts. The results indicate that both cataly'sts are efficient in polyiodide fornation but MMI-disulfide can catalyze this reaction in higher yield and regioselectivity. The complex [(MMI-disulfide) $]^{+}{ }^{+} \mathrm{I}_{2}{ }^{-}$is considered to be formed initially which could be bulkier by addition of excess of iodine in the course of the reaction. These bulky nucleophiles have a fundamental role in the high regioselectivity by attacking the less sterically hindered epoxide carbon. In this study we suggest that MMI is readily converted to MMI-disulfide by interaction with iodine or activated iodine in thy roid gland and this process is responsible for high anti-thyroid activity of MMI.
\end{abstract}

Key Words : Anti-thy roid drug. Methimazole, Ring opening. Polyiodide. Halolydrins

\section{Introduction}

Methimazole (MMI. 1), carbimazole (CBZ. 2), and propylthiouracil (PTU. 3) are currently the most commonly employed dnugs in the treatment of hyperthyroidism. ${ }^{l}$ They depress the formation of thyroid homones 3.5.3'triiodothy ronine $\left(\mathrm{T}_{3}\right)$ and 3.5.3' '. $^{\prime}$-tetraiodothy ronine $\left(\mathrm{T}_{4}\right)$ by' inhibiting the first step of the hormonal biosynthesis which is the incorporation of oxidized iodides into tyrosine residues in the large thyroid homone precursor molecule. thy roglobulin. ${ }^{23}$

These molecules contain the thiourea phannacophore. ${ }^{4-6}$ Because of a push-pull mechanism in which the nitrogen lone pairs donate electrons to the thiocarbonyl group: this pharmacophore must possess significant electron donor properties at the sulfur atom. In an initial proposed mechanism $^{7.8}$ of action of anti-thy roid agents by forming stable complexes with diiodine. they could divert it from the second oxidation step of iodides $\left(\mathrm{I}_{\mathbf{2}} \rightarrow 2 \mathrm{I}^{+}+2 \mathrm{e}^{-}\right)$and consequently prevent the electrophilic substitution of $\mathrm{I}^{+}$on the tyrosine residues of thy roglobulin. Another mechanism ${ }^{3}$ involves an enzyme containing selenocysteine in its active site. which is responsible for the monodeiodination of the prohormone thyroxine $\left(\mathrm{T}_{4}\right)$ to the biologically active hormone $\left(T_{3}\right)$ in the first step in thy roid hormone action. In the deiodinase cycle. the selenol group of the enzyme (E$\mathrm{SeH})$ first reacts with $T_{4}$ to form selenenyl iodides $(\mathrm{E}-\mathrm{SeI})$ with a release of the $T_{3}$. Subsequent reaction of the (E-SeI) with a thiol of other cofactors releases $\mathrm{I}^{-}$and regenerates the active site. The anti-thyroid drugs react with the (E-SeI) intermediate to inhibit the enzyme active site regeneration by formation of a stable selenenyl sulfide

Moreover the catalytic ring opening of epoxides with elemental halogens has been reported in the presence of thiourea and related crown ethers. ${ }^{910}$ Anti-thy roid drugs 1-3 contain the thiourea pharmacophore and we decided to examine the catalytic behavior of these dnigs in the ring opening reactions of epoxides in the presence of elemental halogens. PTU 3 is difficult to study because of insolubility in organic solvents. CBZ 2 in vivo is rapidly and totally metabolized to MMI 1 and the anti-thyroid action of CBZ can be ascribed entirely to MMI. ${ }^{1]}$ So we have selected MMI 1 as a catalyst in a regioselective conversion of epoxides to halohydrins in the presence of elemental iodine. In this study. we wish to report the results of the reactions of epoxides with elemental iodine and bromine in the presence of a catalytic amount of the inexpensive and readily available anti-thyroid drug. methimazole (MMI, 1) and it's wellknown metabolite methimazole-disulfide 4 (Scheme 1).

\section{Results and Discussion}

The results of the reactions of styrene oxide with elemental iodine in the presence of MMI. are sunmmarized in Table 1. For comparison. the cleavage behavior of styrene<smiles>Cn1cc[nH]c1=S</smiles>

1<smiles>CCOC(=O)n1ccn(C)c1=S</smiles>

2<smiles>CCCc1cc(=O)[nH]c(=S)[nH]1</smiles>

3<smiles>Cn1ccnc1SSc1nccn1C</smiles>

4
2<smiles>Cn1cc[nH]c1=[SH+]</smiles><smiles>Cn1ccnc1SSc1nccn1C</smiles> 
Table 1. Reaction of styrene oxide ( $1 \mathrm{mmol}$ ) with elemental iodine (1 $\mathrm{mmol}$ ) in the presence of representative cataly sts

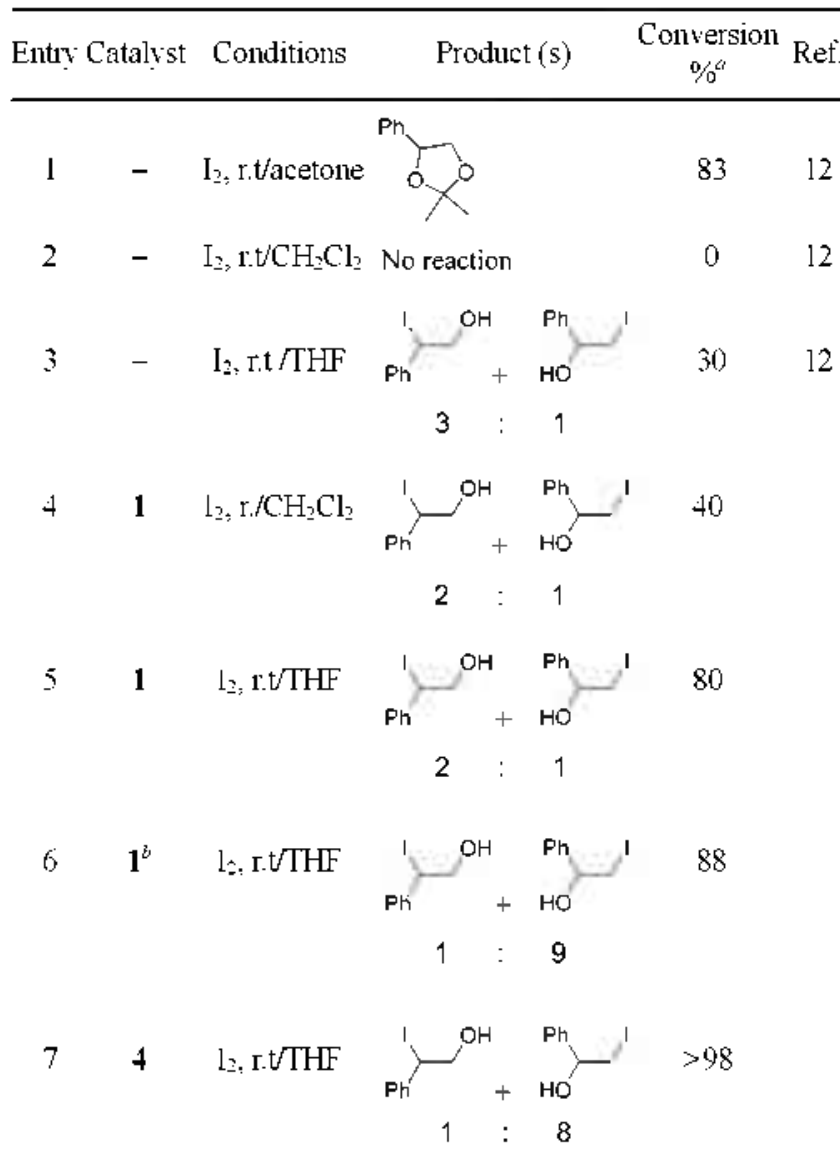

"Relative vield according to $\mathrm{GC}$. "Reaction was carried out with recovered cataly tst

oxide with elemental iodine in the absence of catalyst is given in entries 1-3. As shown in Table 1, iodination of styrene oxide with an excess of elemental iodine in the absence of catalyst does not occur even under reflux and extension of reaction time to several day's. and unreacted styrene oxide are completely recovered. As reported by Turos $^{12}$ and reexamined by us (Table 1 . entry 3 ), iodination cleavage of styrene oxide with iodine in the absence of a cataly st. in THF solvent proceed to only about $30 \%$ conversion with low regioselectivity. Whereas. MMI can catalyze this reaction to completion but the regioselectivity is not sufficient. Interestingly. we observed that the yields and regioselectivity are improved when the reaction is performed in the presence of the recovered catalyst (entry 6). Spectral analysis showed that the catalyst was converted to methimazole-disulfide. It is well known that the thiols can be converted to disulfide in the presence of bromine or iodine. $^{13}$ So. we prepared MMI-disulfide (4) easily from MMI in $90 \%$ yield. and used it as catalyst in the ring opening

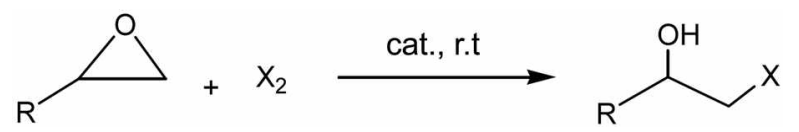

Scheme 2 reactions. The results of the reactions of styrene oxide with elemental iodine in the presence of MMI-disulfide. showed that yield and regioselectivity of the ring opening reaction were increased and catalyst 4 is the most effective one (Table 1, entry 7). We suggest the low reverse-regioselectivity of this reaction in the presence of catalyst 1 (Table 1 , entry 5) is due to the formation of hydroiodic acid and interference in the reaction mechanism course. So, MMIdisulfide $\mathcal{4}$ is the best choice because it's inexpensive and can readily be prepared with high conversion yield in short reaction times.

The results obtained with some representative epoxides in the presence of MMI-disulfide (4) as catalyst are sunmarized in Table 2 and are compared with some other methods. When epoxides were allowed to react in the presence of 4 , increases in yield and regioselectivities were observed in all of the reactions studied. Generally. the optimum amounts of the catalysts were found to be $10 \mathrm{~mole} \%$ of epoxide and halogen. However, bromination is faster than iodination cleavage with similar high yields and regioselectivity.

The regioselectivity and rate of cleaving epoxides by elemental iodine in the presence of a catalyst can be explained in terms of the following suggested mechanisms. ${ }^{9}$

$$
\begin{aligned}
& \text { MMI-disulfide }+2 \mathrm{I}_{2} \rightarrow\left(\text { MMI-disulfide } \cdots \mathrm{I}^{+} \mathrm{I}_{3}^{-}\right. \\
& \text {(MMI-disulfide } \cdots \mathrm{I}^{+} \mathrm{I}_{3}^{-} \rightarrow\left(\text { MMI-disulfide } \cdots \mathrm{I}^{-}+\mathrm{I}_{3}^{-}\right.
\end{aligned}
$$

In support of this mechanism, the UV spectra of iodine, and complex formation between iodine and cataly sts 1 and 4 are shown in Figure 1. None of the initial reactants show any measurable absorption in the $300-440 \mathrm{~nm}$ region. whereas the addition of the catalyst to iodine results in a strong absorption band at $360 \mathrm{~nm}$. presumably due to the complex formation of iodine with catalyst. The intensity of the band at $360 \mathrm{~nm}$. as evidence for the ease of formation of polyiodide ion, decreased in the case of MMI. However. in the case of MMI-disulfide this band appeared immediately and corroborated the much faster complexation of iodine with this catalyst.

The UV-Vis Spectra of iodine in the presence of increasing anounts of MMI-disulfide are shown in Figure 2. While none of the initial reactants show any measurable absorption in the $250-450 \mathrm{~nm}$ region. addition of the catalyst to iodine results in two strong absorption in 290 and $360 \mathrm{~cm}$. due to the formation of iodine-catalyst complexes. It should be noted that the bands of 292 and $364 \mathrm{~nm}$ are characteristic for the fonnation of polyiodide ions such as $\mathrm{I}_{3}^{-}$and $\mathrm{I}_{5}^{-}$, in the process of complex fomation between iodine and electronpair-donating atoms. ${ }^{1+15}$ It is well known that both ions absorb in the same region around 360 and $290 \mathrm{~nm}$ with little 
Table 2. Reaction of Epoxides with Elemental Bromine and Iodine in the Presence of MMI-disulfide (4) as the Catalyst

\begin{tabular}{|c|c|c|c|c|c|c|c|}
\hline Entry & Epoxide & Catalyst & Reaction conditions & Time / h & Yield $/ \% \%^{a}$ & Product (s) & Ref. \\
\hline 1 & & - & $\mathrm{LiI}, \mathrm{AcOH}, \mathrm{THF}, \mathrm{rt}$ & 1.3 & $87(2: 1)$ & & 18 \\
\hline 2 & $"$ & - & $\mathrm{HI}, \mathrm{rt}_{,} \mathrm{CHCl}_{s}$ & 0.25 & $>99$ & & 19 \\
\hline 3 & $"$ & 4 & $1_{2}, 1 \mathrm{tt}, \mathrm{TH}$ & 2 & 85 & & \\
\hline 4 & $"$ & 4 & $\mathrm{BI}, \mathrm{rt}, \mathrm{THF}$ & 1.5 & 89 & & \\
\hline 5 & $"$ & - & $\mathrm{Br}_{2}, 1 \mathrm{t}, \mathrm{CH}_{2} \mathrm{Cl}_{2}$ & l & 31 & & 12 \\
\hline 6 & $"$ & - & $\begin{array}{l}\mathrm{nBu}_{4} \mathrm{~N}^{-} \mathrm{Br}^{-} / \mathrm{Mg}\left(\mathrm{NO}_{3}\right)_{2}, \\
\mathrm{CHCl}_{3} \mathrm{rt}\end{array}$ & 5 & $78(1: 5)$ & & 20 \\
\hline 7 & • & - & $\mathrm{HBr}, \mathrm{Tt}, \mathrm{CHCl}_{3}$ & 025 & $>99$ & & 19 \\
\hline 8 & & 4 & $1_{2}, 1 \mathrm{t}, \mathrm{THF}$ & 4.5 & 92 & & \\
\hline 9 & • & 4 & $\mathrm{Br}_{2}, \mathrm{rt}, \mathrm{THF}$ & 3 & 95 & & \\
\hline 10 & & 4 & $1_{2}, 1 \mathrm{t}, \mathrm{THF}$ & 5.25 & 92 & & \\
\hline 11 & * & 4 & $\mathrm{Br} \mathrm{r}_{-}, \mathrm{rt}, \mathrm{THF}$ & 4 & 95 & & \\
\hline 12 & & 4 & $1_{2}, \mathbf{r t}, \mathrm{THF}$ & 5 & 93 & & \\
\hline 13 & $\bullet$ & 4 & $\mathrm{Br}_{\hat{*}}, \mathrm{rt}, \mathrm{THF}$ & 4.5 & 95 & $\mathrm{DH}$ & \\
\hline 14 & & 4 & $1_{2}, \mathbf{r t}, \mathrm{THF}$ & 2 & 96 & & \\
\hline 15 & * & 4 & $\mathrm{Br}_{\hat{\imath}}, \mathrm{rt}, \mathrm{THF}$ & 125 & 97 & & \\
\hline 16 & & 4 & $L_{\hat{n}, \mathrm{rt}}, \mathrm{TH} F$ & 4 & 75 & & \\
\hline 17 & $\cdot$ & 4 & $\mathrm{Br}_{\hat{*}}, \mathrm{rt}, \mathrm{TH}$ & 3 & 79 & & \\
\hline
\end{tabular}

"Isolated vield.

deviation in their absorbtivities. ${ }^{\text {Ac. } 1 \text { te }}$

Complexation studies of MMI by iodine in a $1: 1.1: 2$ and 2:1 molar ratios. showed that in all of the cases a dark solid complex deposited. In each case. breakdown of the complex upon thiosulfate work up. the same colorless crystal of the MMI-disulfide was obtained and the structure of this product was confirmed by ${ }^{1} \mathrm{H}-\mathrm{NMR}$. IR and MS spectra. Since we believed that the MMI rapidly converted to the MMIdisulfide by a redox reaction with iodine.

The Raman spectra of the MMI: iodine complex which formed in a 1:2 molar ratio are shown in Figures 3. According to the mechanisn and Scheme 1. one half equivalent of iodine consumed for generation of MMI-disulfide from MMI and residue of iodine in the presence of this in situ- 


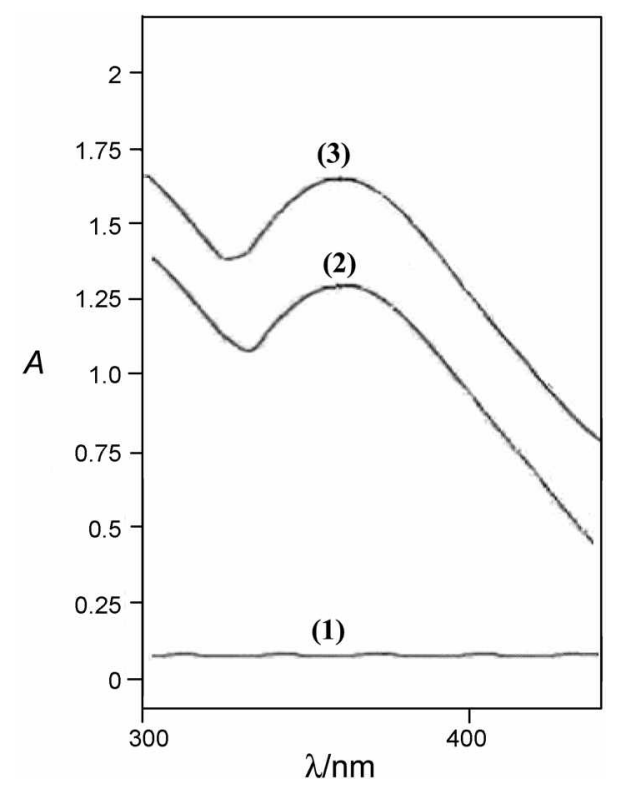

Figure 1. Absorption spectra of: ( 1 ) iodine: (2) and (3) complexes of MMI and MMI-disulfide with iodine in dichloromethane solution respectively.

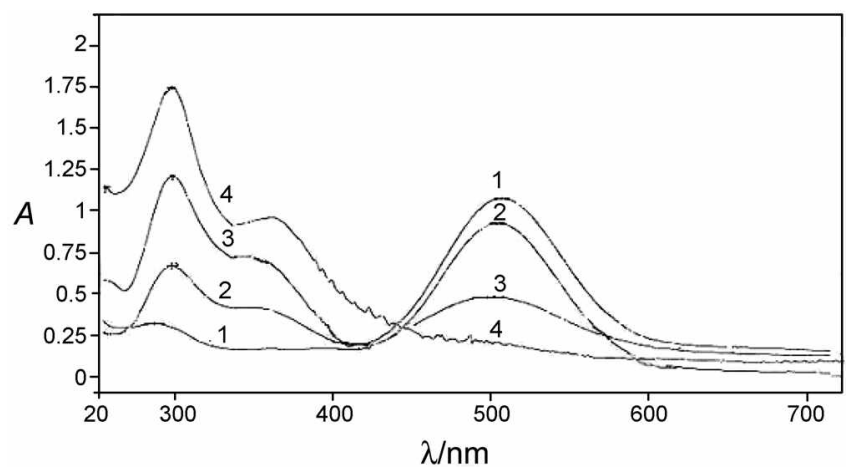

Figure 2. Absorption spectra of iodine in $\mathrm{CH}_{2} \mathrm{Cl}_{2}$ in the presence of various concentration of MMI-disulfide (4). The catalyst: $I_{2}$ mole ratios are: 1) $0.00,2) 0.001,3) 0.01$ and 4) 0.1 .

formed catalyst can be converted to $\mathrm{I}_{\hat{j}}^{-}$and higher polyiodides which showed a series bands at $110.143 .165 \mathrm{~cm}^{-1}$ which intensity of the band at $165 \mathrm{~cm}^{-1}$ increased relative to the band at $110 \mathrm{~cm}^{-1}$. This pattern confurmed the formation of other polyiodides such as $\mathrm{I}_{5}^{-}$. and $\mathrm{I}_{7}^{-}$. This band also shifts to higher wavenumbers until it reaches that of free iodine (approx. $180 \mathrm{~cm}^{-1}$ ). Solid $\mathrm{I}_{2}$ is known ${ }^{16}$ to show a Raman active stretching frequency near $190 \mathrm{~cm}^{-1}$ which was not observed in our spectrum. The Raman spectra of the triiodide anions exhibit a sharp band at 110 and $140 \mathrm{~cm}^{-1}$ corresponding to the symmetrical and unsymmetrical stretching of iodine bonds (Fig. 4). Whereas in the case of MMI-disulfide: iodine complex (1:1), the Raman spectra of the complex showed conversion only up to $\mathrm{I}_{3}^{-}$. evediently. in the case of MMI-disulfide or another catalyst which formed initially $\mathrm{I}_{3}^{-}$, higher polyiodides such as $\mathrm{I}_{3}^{-}, \mathrm{I}_{7}^{-}$, etc were forned in the presence of excess of iodine which provided in catalytic reaction.

Thus we suggest that the major nucleophile at the first of

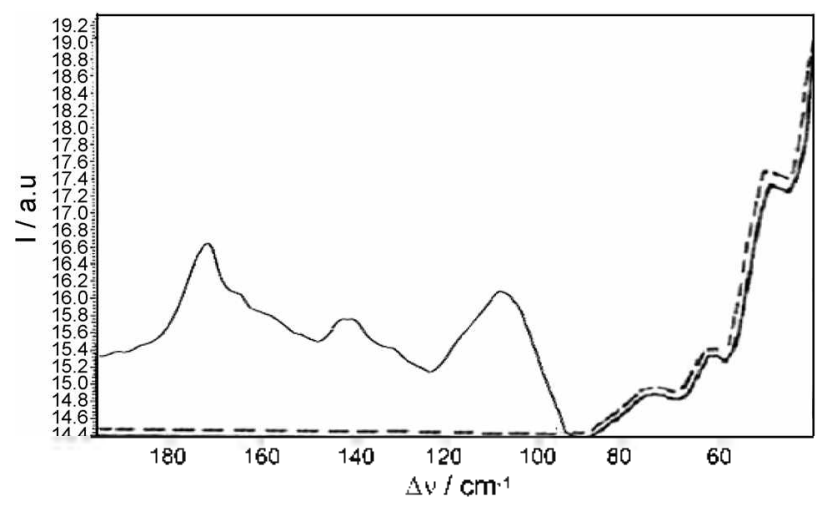

Figure 3. The Raman spectra of MML (---) and MML-iodine (1:2) Complex (-).

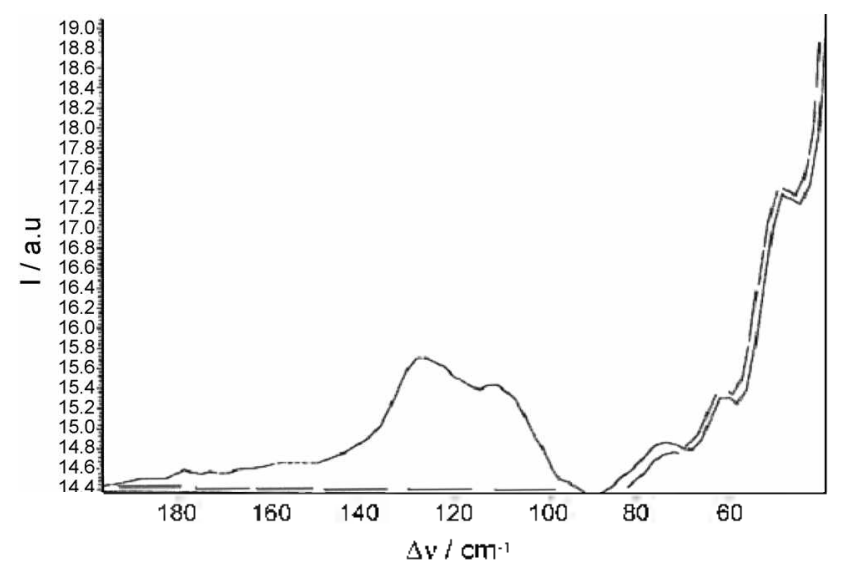

Figure 4. The Raman spectra of MMI-disulfide (--) and MMIdisultide:iodine ( $1: 1)$ complex; (MMI-disulfide $\mathrm{II}^{-} \mathrm{I}_{3}^{-}(-)$.

the reaction is $\mathrm{I}_{3}^{-}$. and this nucleophile is converted to higher bulky polyiodides such as $\mathrm{I}_{5}^{-}$and $\mathrm{I}_{7}^{-}$in the course of the reaction. These bulky nucleoplules have a fundamental role in the high regioselectivity observed attacking on the less sterically hindered epoxide carbon.

The electron donor properties of MMI 1 towards the Lewis acid $\mathrm{I}_{2}$ have already received attention. The MMIdisulfide (4) is the earliest MMI metabolite detected in an in vitro interaction system containing MMI. TPO. $\mathrm{I}_{2}$. and $\mathrm{H}_{2} \mathrm{O}_{2} .{ }^{17}$ Whereas. Laurence et $a l^{4}$ was reported a charge transfer complex. the equilibrium reaction between MMI and iodine has recently been reinvestigated by Isaia et $a t^{18}$ FT-Raman spectra of complexes which formed from $1: 1$ and 1:2 molar ratio of MMI: $I_{2}$, were showed the formation of polyiodide ions such as $\mathrm{I}_{3}^{-}$and $\mathrm{I}_{8}{ }^{2-}$. X-Ray crystallography was proved the formation of MMI-disulfide cations as counter ions of polyiodides. Our observation in MMI and iodine interaction showed that the MMI-disulfide formation is a fast reaction, without any double activation. A simple work up of products by thiosulfate solution. remove the poly iodides and the neutral MMI-disulfide 4 was obtained as colorless crystals in high yields. So. we suggested that MMI by interaction with $\mathrm{I}_{2}$ or activated iodine in thyroid gland such as (E-Sel) readily converted to MML-disulfide and this is responsible for high anti-thyriode activity of MMI. 
In conclusion. we have found that MMI-disulfide which is readily prepared in situ from MMI, can be catalyze the regioselective ring opening of epoxides by elemental iodine and bromine under neutral conditions, as well as the convenience of this procedure. which makes this synthetic technique highly useful. UV-Vis and Resonance Raman spectroscopy indicated that the complex (MMI-disulfide ... $\mathrm{I}^{-} \mathrm{I}_{3}{ }^{-}$is formed. Accordingly, we suggest that the major nucleophile in the first of the reaction is the triiodide ion, $\mathrm{I}_{3}{ }^{-}$ and can be bulkier in the presence of excess of iodine to $\mathrm{I}_{5}{ }^{-}$ and $\mathrm{I}_{7}^{-}$. These bulky nucleophiles play a fundamental role in the high regioselectivity observed. It is due to an attack on the less sterically hindered epoxide carbon. Finally. our results showed that MMI-disulfide is a powerful "iodine sponge" and readily converted it to $\mathrm{I}^{-}, \mathrm{I}_{3}{ }^{-}$. etc. however, this is responsible for high anti-thyriode activity of MMI by depressing the formation of thyroid hormones

\section{Experimental Section}

All materials and solvents were obtained from Merck (Germany) and Fluka (Switzerland). Melting points were determined in open capillary tubes in an Electrothermal IA 9700 melting point apparatus. ${ }^{1} \mathrm{H}-\mathrm{NMR}$ spectra were recorded on a Bruker- $100 \mathrm{MHz}$ instrument using TMS as an internal standard. UV-VIs spectra were obtained with a Shimadzll-AA 670 spectrometer. IR spectra were recorded on a Shimadzu-IR 470 spectrophotometer. The Raman spectrum was recorded employing a $180^{\circ}$ back-scattering geometry and a Bomen MB-154 Fourier Transform Raman spectrometer. It was equipped with a $\mathrm{ZnSe}$ beam splitter and a TE cooled LnGaAs detector. Rovleigh filtration was afforded by a set of two holographic technology filters. The spectrum was collected with a resolution of $4 \mathrm{~cm}^{-1}$ by coadding the results of 1000 scans. The purity deternination of the substrates and reaction monitoring was accomplished by TLC on silica gel polygram SILG/UV 254 plates or GLC on a Shimadzu GC-10A instrument with a flame ionization detector using a column of $15 \%$ carbowax $20 \mathrm{M}$ chromosorb W acid-washed 60-80 mesh. Column chromatography was carried out on short columns of silica gel 60 (230-400 mesh) in glass columns ( $2-3 \mathrm{~cm}$ diameter) using $15-30 \mathrm{~g}$ silica gel per $1 \mathrm{~g}$ of crude mixture.

Preparation of Catalyst. A solution of iodine $(0.254 \mathrm{~g} .1$ mmol) in $\mathrm{CH}_{2} \mathrm{Cl}_{2}\left(5 \mathrm{~cm}^{3}\right)$ was added dropwise to a stirred solution of methimazole $(0.1 \mathrm{~g} .1 \mathrm{mmol})$ in $\mathrm{CH}_{2} \mathrm{Cl}_{2}\left(10 \mathrm{~cm}^{3}\right)$ in $15 \mathrm{~min}$ at roon temperature. The reaction mixture was stirred for $30 \mathrm{~min}$ and then was washed with $10 \%$ aqueous $\mathrm{Na}_{2} \mathrm{~S}_{2} \mathrm{O}_{3}\left(2 \times 10 \mathrm{~cm}^{3}\right)$ and water $\left(2 \times 10 \mathrm{~cm}^{3}\right)$. The organic layer was dried over anhydrous $\mathrm{MgSO}_{4}$ and evaporated. The colorless crystals of methimazole-disulfide were obtained in $90 \%$ vield. Mp. $138^{\circ} \mathrm{C} . \delta_{\mathrm{H}}\left(100 \mathrm{MHz}: \mathrm{CDCl}_{3}: \mathrm{Me}_{4} \mathrm{Si}\right) 3.57$ $(6 \mathrm{H}, \mathrm{s}, \mathrm{Me}), 6.70(4 \mathrm{H} . \mathrm{m}, \mathrm{MMI}) \mathrm{ppm}$. IR $v_{\text {max }} / \mathrm{cm}^{-1}(\mathrm{KBr})$ : $754(\mathrm{~s}) .832(\mathrm{~m}) .845$ (m). 908 (w). 1028 (m). $1180(\mathrm{~m})$, 1217 (m). 1262 (s). 1351 (m). $1390(\mathrm{~m}) .1508$ (w). 1593 (m). 1625 (s). 2920 (w). 2994 (w). 3053 (w): MS $m=228(\mathrm{M}+2)$. $226\left(\mathrm{M}^{+}\right.$). Elemental analysis: (Found: C. 42.45: H. 4.45; N.
24.76; S. 28.34. Calc. for $\mathrm{C}_{8} \mathrm{H}_{10} \mathrm{~N}_{4} \mathrm{~S}_{2}: \mathrm{C}, 42.39 ; \mathrm{H}, 4.50 ; \mathrm{N}$, 24.86: S. $28.39 \%$ ).

General Procedure for Halogenative Cleavage of Epoxides. A solution of epoxide (l $\mathrm{mm}$ l) in THF $\left(5 \mathrm{~cm}^{3}\right)$ was added to a stirred solution of MMI-disulfide $(0.023 \mathrm{~g}$. $0.1 \mathrm{mmol})+$ in THF $\left(5 \mathrm{~cm}^{3}\right)$ at room temperature. Next. a solution of $1 \mathrm{nmmol}$ elemental halogen in THF $\left(10 \mathrm{~cm}^{2}\right)$ was added dropwise during $40 \mathrm{~min}$. The progress of reaction was monitored by TLC and GLC. After complete disappearance of the starting material, the reaction mixture was washed with $10 \%$ aqueous $\mathrm{Na}_{2} \mathrm{~S}_{2} \mathrm{O}_{3}\left(2 \times 10 \mathrm{~cm}^{3}\right)$ and $\mathrm{H}_{2} \mathrm{O}(2 \times 10$ $\mathrm{cm}^{3}$ ). The aqueous layer was further extracted with $\mathrm{CH}_{2} \mathrm{Cl}_{2}$ $\left(2 \times 10 \mathrm{~cm}^{3}\right)$. The combined organic layer was dried over andydrous $\mathrm{MgSO}_{4}$ and evaporated. The crude was purified by chromatography on a column of silica gel. The halohydrins obtained throughout this procedure were identified by comparison with authentic samples prepared according to literature procedures. ${ }^{9,15,19.24}$

The product has been reported before but ${ }^{1} \mathrm{H}-\mathrm{NMR}$ spectral data were not given.

1-Iodo-3-(naphthalen-1-yloxy)-propan-2-ol (entry 10). $\delta_{\mathrm{H}}\left(100 \mathrm{MHz} ; \mathrm{CDCl}_{3} ; \mathrm{Me}_{4} \mathrm{Si}\right) 2.6(\mathrm{lH} . \mathrm{br}, \mathrm{OH}), 3.6(2 \mathrm{H} . \mathrm{m}$, $\left.\mathrm{CH}_{2} \mathrm{I}\right) .4 .0(\mathrm{lH} . \mathrm{m}, \mathrm{CH}), 4.3\left(2 \mathrm{H} . \mathrm{m}, \mathrm{CH}_{2} \mathrm{O}\right), 7.2-7.3(2 \mathrm{H} . \mathrm{m}$, $\mathrm{ArH})$, 7.3-7.6 (3H. m, ArH), 7.7-7.9 (2H. m, ArH).

1-Bromo-3-(naphthaten-1-ploxy)-propan-2-ol (entry 11) $\delta_{\mathrm{H}}\left(100 \mathrm{MHz} ; \mathrm{CDCl}_{3} ; \mathrm{Me}_{4} \mathrm{Si}\right) 2.6(\mathrm{lH}$, br. OH) $3.75(2 \mathrm{H} . \mathrm{m}$, $\left.\mathrm{CH}_{2} \mathrm{I}\right) .4 .1(\mathrm{lH} . \mathrm{m}, \mathrm{CH}), 4.4\left(2 \mathrm{H} . \mathrm{m}, \mathrm{CH}_{2} \mathrm{O}\right), 7.2-7.3(2 \mathrm{H} . \mathrm{m}$, $\mathrm{ArH}), 7.3-7.5(3 \mathrm{H} . \mathrm{m}, \mathrm{ArH}), 7.7-7.9(2 \mathrm{H} . \mathrm{m}, \mathrm{ArH})$.

1-Iodo-3-(naphthaten-2-yloxy)-propan-2-ol (entry 12). $\delta_{\mathrm{H}}\left(100 \mathrm{MHz} ; \mathrm{CDCl}_{3} ; \mathrm{Me}_{4} \mathrm{Si}\right) 2.4(\mathrm{HH} . \mathrm{br}, \mathrm{OH}), 3.5(2 \mathrm{H} . \mathrm{m}$, $\left.\mathrm{CH}_{2} \mathrm{I}\right) .4 .0(\mathrm{lH} . \mathrm{m}, \mathrm{CH}), 4.3\left(2 \mathrm{H} . \mathrm{m}, \mathrm{CH}_{2} \mathrm{O}\right), 6.9(2 \mathrm{H} . \mathrm{m}$, $\mathrm{ArH}) .7 .5(3 \mathrm{H} . \mathrm{m} . \mathrm{ArH}) .7 .85(\mathrm{lH}, \mathrm{m} . \mathrm{ArH}), 8.35(\mathrm{lH}, \mathrm{m}$, $\mathrm{ArH})$.

1-Bromo-3-(naphthaten-2-yloxy)-propan-2-ol (entry 13). $\delta_{\mathrm{H}}\left(100 \mathrm{MHz} ; \mathrm{CDCl}_{3} ; \mathrm{Me}_{4} \mathrm{Si}\right) 2.6(\mathrm{lH}$, br. $\mathrm{OH}) .3 .68(2 \mathrm{H} . \mathrm{m}$, $\left.\mathrm{CH}_{2} \mathrm{I}\right) .4 .1(\mathrm{lH} . \mathrm{m}, \mathrm{CH}), 4.4\left(2 \mathrm{H} . \mathrm{m}, \mathrm{CH}_{2} \mathrm{O}\right), 6.9(2 \mathrm{H} . \mathrm{m}$, $\mathrm{ArH}), 7.5(3 \mathrm{H} . \mathrm{m} . \mathrm{ArH}) .7 .85(\mathrm{lH}, \mathrm{m} . \mathrm{ArH}), 8.35(\mathrm{lH}, \mathrm{m}$, $\mathrm{ArH})$.

\section{References}

1. Buxerand. T. In Traite de Chintie Therapentiqute: Tec et Doc Lavoisier: Paris. 1995: vol. 4. ch. 18.

2. Roy: G.: Nethaji. M.: Mugesh. G. Org. Bionol. Chem. 2006. $t$. 2883.

3. Roy, G.: Mugesh. G. Phosphorus. Sulfur and Silicon 2005, 180. 891

4. Laurence. C.: El-Ghomari. M. J.: Le Questel. T.Y.: Berthelot. M.: Mokhlisse. R. J. Chent. Soc. Perkin Trans. 2 1998. 1545.

5. (a) Laurence. C.: El-Ghomari. M. J.: Berthelot. M. J. Chem. Sox. Perkin Trons. 2 1998. 1163; (b) Laurence. C. El-Ghomari. M. J.; Lucon. M. J. Chem. Soc. Perkin Trans. 21998.1159.

6. Corban. G. J; Hadjikakou, S. K; hadjiliadis, N.: Kubicki, M: Tiekink. E. R. T.: Butler. I. S.: Drougas. E.: Kosmas. A. M. Inorg. Chent 2005. 4. 8617.

7. Buxeraud. I.: Absil. A. C.: Claude. J.: Raby. C.: Catanzano. G.: Beck. C.J.Med Chem 1985, 20,43.

8. Raby, C: Lagoree, A. C.; Jambut-Absil, A. C.: Buxeraud. J. Catanzano, G. Endocrimology 1990. 126, 1683.

9. Sharghi. H.: Massah. A. R.: Eshghi. H.: Nikinam. K. J. Org Chen. 
1998. 63.1455

10. (a) Sharghi. H.: Eskandari. M. M. Tetrohedron 2003. 59. 8509. (b) Sharghi. H.: Paziraee. Z.: Niknam. K. Bull. Korean Chem. Soc. 2002, 23, 1611

11. (a) Nakashima. T.: Taurog A. Chm. Endocrinol. 1979.10,637. (b) Melander A.: Hellengren. B.: Rosendal-Helgesen. S: Sjoberg. A. K.: Wallin-Boll. E. Eur, J. Chn. Pharmacol 1980. 17. 295. (c) Jansson. R.: Dalhberg. P. A.: Lindstrom. B. Int. J. Chn. Phamtacol. Ther Toxicol 1983. 21. 505.

12. Konaklieva. M. I.: Dahi. M. L.: Turos. E. Tetrahedron Latt 1992. 33(47), 7093 .

13. (a) Corey. E. I.: Brunelle. D. I. Tetratredron Lett. 1976. 3409. (b) Frank. R. L.: Blegen. J. R. Organic Sintheses. Coll. rot. 31955. 116

14. (a) Semnani. A.: Shamsipur. M. J. Chem. Soc. Dalton Trans. 1996, 2215 . (b) Mizuno. M: Tanaka, J: Harada, I. J. Phns. Chem. 1981. 85. 1789. (c) Andrews. L. I.: Prochaskia, E. S.: Loewenschuss, A. Inorg. Chem. 1980, 19, 463. (d) Lang. R. P. J. Plys. Chem. 1974. 78. 1657. (e) Buckles. R. E.: Yuk. J. P.: Popov. A. I. J. Am. Chem. Soc. 1952. 74. 4379. (t) Deplano. P.: Ferraro. J. R: Mercuri. M. L.: Trogu. E. F. Coord Chem. Rev: 1999. 188. 71.
15. (a) Nour. E. M.: Shahada. L. M. A. Sifectrochim. Acta Part .A 1988. 4t. 1277. (b) Nour. E. M. Ibid 1991. 47. 743. (c) Nour. E. M. Ibid. 1999.56. 167 .

16. Nour. E. M; Chen. L. H; Laane, J. J. Plys. Chem. 1986. 90. 2841.

17. Taurog, A.; Dorris, M. L:- Guziec, F. S. Endocinology 1989, 124. 30.

18. Aragoni. M. C.: Arca. M.: Demartin. F.: Devillanova. F. A.: Garau. A.: Isaia. F.: Lippolis. V: Verani. G. $J$. Am. Chem. Soc. 2002 . 124. 4538.

19. Bajwa. J. S. Anderson, R. C. Tetrahedron Lett. 1991. 32.3021.

20. Chini, M.: Crotti. P.: Gardelli. C.; Macchia, F. Tetrahedron 1992. 48. 3805 .

21. Suh. Y. G: Koo. B. A.: Ko. J. A.: Cho. Y. S. Chent Lett 1993. 1907.

22. Irampoor, N.: Kazemi, F.; Salehi. P. Synth. Conmun. 1997. 27. 1247.

23. Sabitha, G.: Babu, R. S.: Rajkumar. M.; Reddy, C. S.; Yadav. J. S. Tetrahedron Lett. 2001. +2.3955

24. Reddy: M. A.: Surendra. K.: Bhanumathi. N.: Rao. K. R. Tetrohedron 2002. 58. 60003. 